\title{
Neo-clinicians, Clinical Trials, and the Reorganization of Medical Research in Paris Hospitals after the Second World War: The Trajectory of Jean Bernard
}

\author{
CHRISTELLE S RIGAL*
}

Between 1940 and 1970, medical research was transformed. In France, as well as in Britain, this transformation has often been associated with the renewed importance of experimental medicine. Like the actors who participated in this transformation, historians have highlighted the "biologization" of medicine that took place and was advocated by a new generation of clinicians and fundamental biologists. ${ }^{1}$ Together, they believed that medicine needed greater input from virology, bacteriology, immunology, embryology and biochemistry, and required new spaces where clinical questions could be translated into experimental systems, examined and manipulated. In France, the Institut National d'Hygiene (INH, National Institute for Health), created under the Vichy regime, became the home institution for many researchers working on disease causation, transmission, and evolution. In the 1960s, a major reform of medical teaching and organization carried out under the presidency of General de Gaulle resulted in the creation of dozens of hospital laboratories, which participated in these developments. ${ }^{2}$ However, in the eyes of French post-war medical reformers, biology was not the "single best way" to make medicine more scientific. Another was to trust in numbers, to mobilize statistics and quantitative tools for evaluating the effects of medical care and therapeutic intervention. In contrast to the biological route, the statistical path was highly problematic,

(C) Christelle S Rigal 2008

*Christelle S Rigal, PhD, CERMES, Site CNRS, 7 rue Guy Môquet, 94801 Villejuif cedex, France; e-mail: rigal@vjf.cnrs.fr

${ }^{1}$ Ilana Löwy, Olga Amsterdamska, John
Pickstone and Patrice Pinell (eds), Medicine and
change: historical and sociological studies of medical
innovations, Montrouge, John Libbey Eurotext, and
Paris, INSERM, 1993, pp. 181-262; I Löwy, Between
bench and bedside: science, healing, and interleukin-
2 in a cancer ward, Cambridge, MA, Harvard
University Press, 1996; John Krige and Dominique
Pestre (eds), Science in the twentieth century,
Amsterdam, Harwood Academic Publishers, 1997,
pp. $439-546 ;$ Soraya de Chadarevian and Harmke
Kamminga (eds), Molecularizing biology and
medicine: new practices and alliances, 1910s-1970s,

Amsterdam, Harwood Academic Publishers, 1998; Roger Cooter and John Pickstone (eds), Medicine in the twentieth century, Amsterdam, Harwood Academic Publishers, 2000, pp. 347-449; Jean-Paul Gaudillière, Inventer la biomédecine: la France, l'Amérique et la production des savoirs du vivant, Paris, La Découverte, 2002; Peter Keating and Alberto Cambrosio, Biomedical platforms: realigning the normal and the pathological in late-twentiethcentury medicine, Cambridge, MA, MIT Press, 2003.

${ }^{2}$ Jean-François Picard, 'Poussée scientifique ou demande de médecins? La recherche médicale en France de l'Institut National d'Hygiène à l'INSERM', Sciences Sociales et Santé, 1992, 10: 47-106; Jean-François Picard, 'De la médecine expérimentale (1865) à l'INSERM (1964)', in Claude Debru, Jean Gayon, and Jean-François Picard (eds), Les sciences biologiques et médicales en France, 1920-1950, Paris, CNRS Editions, 1994, pp. 329-43. 


\section{Christelle S Rigal}

meeting resistance, if not outright hostility, from clinicians, with the result that the eventual "mathematization" of French medical research has been attributed to external pressures, resulting either from the newly found political influence of INH statisticians, or from the new research questions and tools imported from Britain and the United States, where quantification in the clinic as well as in public health had long benefited from wide support. ${ }^{3}$ According to this perspective, in contrast to their colleagues in Britain and the USA, French medical reformers favoured a form of biomedicine which, despite recognizing the importance of molecules and macromolecules, was characterized by a physiological approach to the understanding of disease and therapeutic efficacy, and allowed clinical trials only a limited role in selecting the optimal mode of medical intervention.

This paper examines this scenario, focusing on the example of cancer research in France. There-as elsewhere-cancer research received impetus from public charities, benefited from increased government funding, and took a fresh turn after the Second World War, with new investigation into viruses, mutations, and immunological responses. However, while French achievements in risk factor epidemiology, which were largely due to the work of a small group of medical statisticians located within the INH, have been widely acknowledged, the French contribution to what was the most important change in cancer treatment, namely the rise of cancer chemotherapy in the 1960 s and 1970 s, is barely remembered. ${ }^{4}$ As a consequence, the existence of a clinical path toward controlled trials, and the quantification of bedside research that accompanied it, has tended to be overlooked in the case of France.

In order to fill this gap in the literature and test the hypothesis that French "neoclinicians" created a small, but none the less significant, medical world in which biomedicine was synonymous with diagnosis as well as treatment, with clinical trials as well as macromolecules, with patients as well as animal models, this paper examines the trajectory of Jean Bernard and his co-workers. Jean Bernard was one of the "neo-clinicians" who argued in favour of the reform of medical research in France after the Second World War, emphasizing the need for institutional and intellectual changes that would reinforce the role of biology and statistics in the practice of medicine. That this was not mere rhetoric is revealed by the work on acute leukaemia carried out by Bernard and his team at the centre for research on leukaemia and blood diseases in

\footnotetext{
${ }^{3}$ J Rosser Matthews, Quantification and the quest for medical certainty, Princeton University Press, 1995; Harry M Marks, The progress of experiment: science and therapeutic reform in the United States, 1900-1990, New York, Cambridge University Press, 1997; Eileen Magnello and Anne Hardy (eds), The road to medical statistics, Amsterdam and New York, Rodopi, 2002; Gérard Jorland, Annick Opinel and George Weisz (eds), Body counts: medical quantification in historical and sociological perspective, Montreal, McGill-Queen's University Press, 2005.

${ }^{4}$ For the history of cancer research in France before 1945, see Patrice Pinell, Naissance d'un fléau:
}

histoire de la lutte contre le cancer en France, 1890-1940, Paris, Métailié, 1992. For the post-war reorganization of scientific and medical research in France, see Jean-François Picard, La république des savants: la recherche française et le CNRS, Paris, Flammarion, 1990; Picard, op. cit., note 2 above; Gaudillière, op. cit., note 1 above. For the history of medical statistics in France, see Luc Berlivet,

'Exigence scientifique et isolement institutionnel: l'essor contrarié de l'épidémiologie française dans la seconde moitié du XXe siècle', in Jorland, et al. (eds), op. cit., note 3 above, pp. 335-58; Luc Berlivet's paper in this issue; Gaudillière, op. cit., note 1 above, pp. 218-45. 


\section{Medical Research in Paris Hospitals after the Second World War}

the Hôpital Saint-Louis in Paris, which took an active part in international cancer research, and helped to establish chemotherapy as a major form of treatment for cancer in the 1960 s and 1970s.

In this context, the development of trial protocols, the use of control groups, and the application of computational techniques were advocated as means for the production of standards and norms that would ensure greater comparability, homogeneity, control and "objectivity" of medical practices. However, these did not lead to a complete substitution of traditional-mainly qualitative-clinical research by quantitative approaches. By following the introduction of controlled clinical trials in one particular setting, that of the Saint-Louis Hospital, this paper also shows that the project for modernizing and rationalizing French medical research was in large part inspired by cancer research in the United States, including its commitment to an industrial model of research organization. However, paradoxically, in France this project was not based on the mounting influence of private pharmaceutical firms, but rather-in a way reminiscent of British medicine-on state-supported quasi-universal access to health care, with its cortège of massive investments, and alleged co-ordination and control. ${ }^{5}$

My argument is developed in three parts. First, I summarize Jean Bernard's scientific and medical career as it exemplifies the trajectory of many French biomedical reformers. Second, I focus on Bernard's research on leukaemia, analysing the evolution of his clinical trial methodology, and examining the relationship between this evolution and the transformation of leukaemia research in the USA. In the last section, I relate these cognitive and practical changes to the political and institutional reorganization of medical research in 1960s France, which helped to make these changes a reality.

\section{Jean Bernard's Early Medical Career}

Before studying Bernard's work in Paris and following his trajectory towards statistically based controlled clinical trials, it is worth saying a few words about his early career. Jean Bernard was born in Paris in 1907. In 1929, he took an internship under Paul Chevallier, a physician from the Assistance Publique des Hôpitaux de Paris (APHP), who had first qualified in dermatology and then specialized in blood disorders. ${ }^{6}$ In 1930s France, haematology was still a minor discipline, obsessed with discussions about nomenclature and tissue genesis, and haematological disorders were described and classified by correlating clinical signs with microscopic findings. Thus, Bernard's first publications, which were co-authored with Chevallier, were mainly concerned with the description and characterization of diseases of the lymphatic system. Between 1930 and 1935, Bernard also helped the paediatrician Robert Debré and the veterinary surgeon Gaston Ramon to develop a diphtheria vaccine at the Pasteur Institute. ${ }^{7}$

\footnotetext{
${ }^{5}$ See John Stewart's paper in this issue.

${ }^{6}$ Thérèse Bertrand-Fontaine, 'Paul Chevallier (1884-1960)', Bulletins et Mémoires de la Société médicale des Hôpitaux de Paris, 1960, 76: 879-80; anon., 'Paul Chevallier (1884-1960)', Bulletins et
}

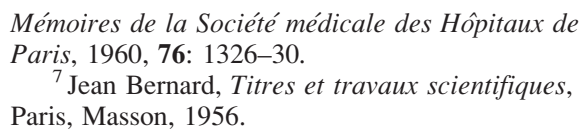




\section{Christelle S Rigal}

Bernard prepared his doctoral thesis in the laboratory of André Lemierre, professor of infectious diseases. Published in 1936, his MD thesis showed that the injection of coal tar into the bone marrow of rats induced leukaemia and lymphomas. ${ }^{8}$ These experiments contributed to the classification of leukaemia as a neoplastic disease, thereby helping to settle the question of its cancerous nature. During the war, Bernard worked in a surgical ambulance team, where he treated war wounds with sulphonamides. He joined the French resistance in southern France, before serving as a physician in the army. Then, in 1946, having passed the highly competitive examination of Médecin des Hôpitaux de Paris, he joined the paediatric department of the Hérold Hospital.

During the war, the activities of paediatric departments had been profoundly transformed. The introduction of penicillin and the sulphonamides revolutionized the prognosis of many infectious diseases, so that the only terminally ill patients remaining in the wards were children suffering from leukaemia or cancer. Bernard therefore chose to concentrate on these diseases, and combine traditional bedside medicine with experimental studies. ${ }^{9}$ In 1946, having agreed to work on leukaemia with the biologist Marcel Bessis, the latter put at his disposal a small laboratory at the Centre National de Transfusion Sanguine (National Centre for Blood Transfusion), which was equipped with experimental tools and animals. ${ }^{10}$ Later, Bernard turned rooms in the cellar of the Hérold Hospital into a small research laboratory. ${ }^{11}$

At that time, leukaemia was suspected when swelling of the haematopoeitic organs, haemorrhages, pallor, and infections appeared. Microscopic examination of the patient's blood was necessary to confirm the diagnosis, and leukaemia sub-classification was based on the histological study of normal white blood cells. Thus, acute leukaemia was defined as an increase of normal mature white cells, combined with a high rate of abnormal immature white cells in blood. However, dissatisfied with such classification, Bernard in 1947 began reviewing the files of about 150 acute leukaemia patients in search of more precise diagnostic criteria. As a result, he was able to show that initial symptoms evoked acute leukaemia in only 30 per cent of the cases, and that in most cases the bone marrow had contained many leukaemia cells (morphologically abnormal immature white cells) even before these had appeared in the blood. Hence, he proposed that the final diagnosis should be based on bone-marrow examination. ${ }^{12}$ Another type of

\footnotetext{
${ }^{8}$ Jean Bernard, Polyglobulies et leucémies provoquées par des injections intramédullaires de goudron (Thèse de médecine), Paris, G Doin, 1936, p. 163.

${ }^{9}$ Jean Bernard, Médecin dans le siècle, Paris, Robert Laffont, 1994, pp. 105-17. Archives de l'APHP, cote 773 Foss 2, personnels médecins. Archives de l'APHP, logiciel Miramion.

${ }^{10}$ Some of these tools and animals had been provided by Dr K J Randall from Guy's Hospital in London. Archives de l'académie de médecine, Fonds Bessis, correspondence with Jean Bernard, 1 Oct. 1946, 3 Dec. 1946, letter from K J Randall to Jean Bernard, 14 Jan. 1947; interview with Jean Bernard, 19 Feb. 1999.
}

\footnotetext{
${ }^{11}$ Archives Nationales, Versement 2002192, article 16, correspondence with Robert Mallet, 22 April 1959.

${ }^{12}$ Maxwell Wintrobe, Hematology: the blossoming of a science, Philadelphia, Lea and Febiger, 1985, p. 58; Justin Jolly, Le sang dans la vie de l'organisme, Paris, Flammarion, 1946, p. 223; Jean Bernard, 'Le diagnostic et le traitement des leucoses aiguës', La Semaine des Hôpitaux de Paris, 1948, 24 (23): 730-6; Jean Bernard and Georges Mathé, 'La discordance des moelles au cours des leucoses aiguës', Bulletins et Mémoires de la Société médicale des Hôpitaux de Paris, 1951, 67 (29-30): 1285-91; Bernard, op. cit., note 7 above.
} 


\section{Medical Research in Paris Hospitals after the Second World War}

research in which Bernard participated after the Second World War involved the use of radioactive molecules. For instance, in 1952, working with the head of the Military Health Service, he injected radiolabelled white blood cells into healthy volunteers and patients with leukaemia in order to compare their circulation in normal and pathological conditions. ${ }^{13}$

In 1957, Bernard left the paediatric department at the Hérold Hospital to head the paediatric department at the Saint-Louis Hospital. ${ }^{14}$ There, a new building entirely devoted to haematological research, called the Hayem Centre, was built for him and his team in $1960 .^{15}$

\section{Statistics and Clinical Medicine: Local Paths to Controlled Clinical Trials}

Bernard ran his first therapeutic experiment at the beginning of the 1940s, when he injected colchicine, the alkaloid of meadow saffron, into the bone marrow of seven of his patients. However, he found the results from this experiment unsatisfactory. Although the state of every patient's bone marrow had improved, in only two cases did their general health improve, and this at best for a few months. Moreover, colchicine was difficult to use, since it had no effect when given either orally or intravenously. Bernard made no further attempt to treat human leukaemia until $1947 .{ }^{16}$ His renewed efforts at treating leukaemia reflect the "biomedicalization" of cancer that was taking place, in France as elsewhere, and involved using chemical compounds to poison cancer cells on the one hand, and statistically based controlled trials on the other. However, they also illustrate the fact that the emergence of a trial culture in a French context was the product of local circumstances stimulating biomedical reform, as well as of a new transatlantic circulation of tools, results, and (less often) researchers.

It is well known that during the second half of the twentieth century, controlled clinical trials became standard practice for assessing the efficacy of medical treatments. In the 1960s and 1970s, first in the United States, and then in Europe, the randomized controlled trial (RCT) gradually became accepted as the most objective procedure, and after the 1962 amendments to the American Food, Drug and Cosmetics Act, became a requirement for drug marketing authorization. Historians who have studied clinical trials have analysed their characteristics and their gradual adoption by clinical researchers. ${ }^{17}$

\footnotetext{
${ }^{13}$ J Julliard, B Maupin, A Loverdo, J Bernard, P Calvez, M Lecomte, J Dugas, R Ardry, F Henaff, F Perrot, et al., 'Premiers essais de transfusion à l'homme de leucocytes et de plaquettes marqués au radio-phosphore', La Presse Médicale, 1952, 60 (24): 518-520.

${ }^{14}$ Archives de l'APHP, cote 773 Foss 2 , personnels médecins.

${ }^{15}$ Archives Nationales, Versement 2002192, article 45, Bâtiment provisoire, Centre Hayem.

${ }^{16}$ Jean Bernard, 'Les injections intra-médullaires chez l'homme', Le Sang, 1946, 17: 61-5.

${ }^{17}$ Abraham Lilienfeld, 'Ceteris paribus: the evolution of the clinical trial', Bull. Hist. Med., 1982, 56: 1-18; Anne Fagot-Largeault, 'Les origines de la
}

notion d'essai contrôlé randomisé en médecine', Cahiers d'Histoire et de Philosophie des Sciences, 1992, 40: 281-300; Matthews, op. cit., note 3 above, pp. 115-40 ; Ted J Kaptchuk, 'Intentional ignorance: a history of blind assessment and placebo controls in medicine', Bull. Hist. Med., 1998, 72: 389-433; A

Yoshioka, 'Use of randomisation in the Medical Research Council's clinical trial of streptomycin in pulmonary tuberculosis in the 1940s', Br. med. J., 1998, 317: 1220-3; Marks, op. cit., note 3 above, pp. 136-63; Harry M Marks, 'Trust and mistrust in the marketplace: statistics and clinical research, 1945-1960', Hist. Sci., 2000, 38: 343-55; idem, 'Confiance et méfiance dans le marché: les statistiques et la recherche clinique (1945-1960)', 


\section{Christelle S Rigal}

Most of the historical work examining the development of controlled clinical trials has located their origin in the United Kingdom and in the United States. Moreover, it has generally described their evolution as resulting from the simultaneous emergence of a community of statisticians specialized in medical research, and of a group of "clinical reformers" convinced firstly that biology and statistics are indispensable to medical progress, and secondly that therapeutic experimentation is necessary, even for "incurable" diseases. Modern therapeutic evaluation can therefore be viewed as the product of the convergence between the evolution of statistical concepts and methodologies, and attempts by physician-experimenters to reduce the biases inherent in the selection of patients. ${ }^{18}$ However, it would be naïve to believe that the generalization of the RCT was simply a question of methodological progress. As Harry Marks has pointed out in the American context, such techniques as group control and randomization were promoted by an unexpected alliance between élite physicians, who were suspicious of both general practitioners and drug manufacturers, and officials from the Food and Drug Administration, anxious to control the pharmaceutical market and limit the number of drugs without therapeutic value, in order to force the industry to organize controlled (but not necessarily randomized) trials. ${ }^{19}$

Many clinicians viewed those trials, in particular randomized trials, with reluctance or even opposition. Various reasons have been put forward to explain this reluctance. Firstly, the strength of clinical "tradition", emphasizing the individuality of patients and diseases as well as the importance of the physician's experience and clinical "judgement", has been seen as incompatible with the population-based approach involved in therapeutic evaluation. ${ }^{20}$ This aspect is often related to a second explanation, namely the physician's lack of training in statistics, itself linked to the institutional weakness of medical statistics. ${ }^{21}$ Thirdly, randomization and placebos were often considered to be unethical by clinicians because they imply giving a treatment to patients

Sciences Sociales et Santé, 2000, 18 (4): 9-25; JeanPaul Gaudillière, 'Beyond the one-case statistics: mathematics, medicine, and the management of health and disease in the postwar era', in Umberto Bottazzini and Amy Dahan Dalmedico (eds), Changing images in mathematics: from the French Revolution to the new millenium, London and New York, Routledge, 2001, pp. 281-96; Eileen Magnello, 'The introduction of mathematical statistics into medical research: the roles of Karl Pearson, Major Greenwood and Austin Bradford Hill', in Magnello and Hardy (eds), op. cit., note 3 above, pp. 95-123; Löwy, Between bench and bedside, op. cit., note 1 above, pp. 36-83; I Löwy, 'Essai clinique', in Dominique Lecourt (ed.), Dictionnaire de la pensée médicale, Paris, PUF, 2004, pp. 441-6; Iain Chalmers, 'Statistical theory was not the reason that randomization was used in the British Medical Research Council's clinical trial of streptomycin for pulmonary tuberculosis', in Jorland, et al. (eds), op. cit., note 3 above, pp. 309-34; G Weisz, 'From clinical counting to evidence-based medicine', in ibid., pp. 377-93; Theodore Porter, 'Medical quantification: science, regulation, and the state', in ibid., pp. 394-401. See also Marcia L Meldrum,

'Departures from the design: the randomized clinical trial in historical perspective, 1946-1970', PhD thesis, State University of New York at Stony Brook, 1994; Desiree Cox-Maximov, 'The making of the clinical trial in Britain, 1910-1945: expertise, the state and the public', PhD thesis, Cambridge University, 1997; B Toth, 'Clinical trials in British medicine, 1858-1948, with special reference to the development of the randomised controlled trial', $\mathrm{PhD}$ thesis, University of Bristol, 1998.

${ }^{18}$ Marks, op. cit., note 3 above, pp. 136-55; Gaudillière, op. cit., note 17 above, pp. 282-9; Chalmers, op. cit., note 17 above.

${ }^{19}$ Marks, 'Trust and mistrust', op. cit., note 17 above.

${ }^{20}$ Matthews, op. cit., note 3 above, pp. 134-8; Gaudillière, op. cit., note 17 above, pp. 281-2; Weisz, op. cit., note 17 above, pp. 385-6; Löwy, Between bench and bedside, op. cit., note 1 above, pp. 49-50.

${ }^{21}$ Fagot-Largeault, op. cit., note 17 above, p. 285; Marks, op. cit., note 3 above, pp. 148-55. 
without any obvious reasons for considering it effective, thereby transforming these patients into laboratory animals. ${ }^{22}$ Alternatively, if the treatment is to all intents and purposes thought to be effective, then it is unethical to deny the therapy to half the sample population.

The fact that physicians' reluctance to adopt controlled clinical trials was eventually overcome has been described as the consequence of practical, scientific and regulatory factors. In the aftermath of the Second World War, interest in controlled trials was strengthened by the large-scale release onto the medical market of more effective and vigorously advertised pharmaceutical products, like the sulpha-drugs and antibiotics. Under pressure from patients keen to try new treatments, but suspicious of pharmaceutical firms' claims of efficacy, physicians began to accept clinical trials as a means of organizing clinical judgement, strengthening their expertise, making the allocation of drugs easier, and facilitating difficult therapeutic decisions. This trend was reinforced in the 1960s by regulatory measures, which-in the United States at least-transformed controlled trials into powerful administrative tools. ${ }^{23}$

Another explanation for the eventual acceptance of controlled clinical trials by clinicians, which is less often mentioned but plays an important role in our story, is the establishment of laboratories within medical research institutes, which introduced the idea of experimental control. ${ }^{24}$ This was echoed in the books and articles written by statisticians recruited into these institutions, which drew analogies between "basic" research and controlled clinical trials in order to familiarize clinicians with medical statistics. ${ }^{25}$ An analysis of Bernard and his co-workers' research on leukaemia demonstrates this. It also shows important differences between the Parisian scene and American cancer research, both in terms of trial methodology, and the ways in which this new form of medical "scientificity" was appropriated.

Bernard's first therapeutic experiments on humans at the beginning of the 1940s had ended following a combination of technical difficulties and ambiguous results. ${ }^{26} \mathrm{~A}$ few years later, between 1947 and 1950, Bernard and Bessis treated-in a way typical of local clinical and physiological innovation-about twenty patients with so-called exsanguino-transfusion, a technique for replacing nearly all a leukaemia patient's blood with that of donors. ${ }^{27}$ The fact that some colleagues argued that remissions observed after the treatment were spontaneous led them to devise quantitative criteria for contrasting "improvements" with "partial remissions" and "complete remissions", and for comparing

\footnotetext{
${ }^{22}$ Matthews, op. cit., note 3 above, pp. 131-8; Marks, op. cit., note 3 above, 155-8; Kaptchuk, op. cit., note 17 above, p. 429.

${ }^{23}$ Fagot-Largeault, op. cit., note 17 above, p. 284; Marks, 'Trust and mistrust', op. cit., note 17 above; Marks, The progress of experiment, op. cit., note 3 above, pp. 149-50; Kaptchuk, op. cit., note 17 above, pp. 418-24; Gaudillière, op. cit., note 17 above, p. 287; Lilienfield, op. cit., note 17 above, pp. 12-13; Matthews, op. cit., note 3 above, pp. 134-5;

Yoshioka, op. cit., note 17 above, p. 1222.

${ }^{24}$ Yoshioka, op. cit., note 17 above, p. 1221; Kaptchuk, op. cit., note 17 above, p. 427.
}

\footnotetext{
${ }^{25}$ Matthews, op. cit., note 3 above, pp. 120-5; Marks, op. cit., note 3 above, pp. 139-41.

${ }^{26}$ Bernard, op. cit., note 16 above.

${ }^{27}$ Marcel Bessis and Jean Bernard, 'Remarquables résultats du traitement par l'exsanguino-transfusion d'un cas de leucémie aiguë', Bulletins et Mémoires de la Société médicale des Hôpitaux de Paris, 1947, 63: 871-7; Marcel Bessis and Jean Dausset, 'Etude critique des rémissions au cours des leucémies aiguës traitées par exsanguinotransfusion', Rev. Hémat., 1950, 5: 188-225.
} 


\section{Christelle S Rigal}

the frequency of the latter with that of the "spontaneous" but complete remissions reported in the literature. ${ }^{28}$ According to Bernard and his colleagues, it was not possible to argue that exsanguino-transfusion prolonged life, because the mean survival time of untreated patients was not known precisely enough, and data varied considerably from one specialist to another. ${ }^{29}$ Hence the treatment was abandoned, not because it had failed, but because it was too difficult to generalize and laboratory work was unlikely to improve the results.

The mixed results of exsanguino-transfusion made the American alternative, namely the chemotherapeutic use of folic acid antagonists, appear more attractive. As is well known, Sidney Farber's team conducted the first trials of folic acid antagonists in acute leukaemia in Boston in 1947. ${ }^{30}$ Some ten other groups in the United States and in Europe rapidly began testing these compounds. No pre-established treatment protocol was used, and the evolution of the disease in treated patients was compared with what had been observed before potential drugs became available. In Paris, the first results obtained with the antagonists supplied by the American firm Lederle Laboratories were not spectacular; they were equivalent to those obtained with exsanguino-transfusion. However, the use of molecules was simpler than the substitution of a patient's blood, and chemotherapy was considered more promising on the grounds that specific chemicals to kill specific cells would eventually be found. Though interesting, the results obtained by the ten other groups were neither similar, nor even comparable. Practices differed, in particular regarding dosage and treatment schedule. In addition, the criteria used to assess the efficacy of folic acid antagonists were not identical; the evaluation of the most effective molecules differed, as well as the inventory of their effects on the clinical status of the patients. Among the reported trials, the only shared conclusion was that folic acid antagonists were able to induce remissions. ${ }^{31}$

\footnotetext{
${ }^{28}$ Bessis and Dausset, op. cit., note 27 above; R Fauvert, J Mallarmé and P Petit, 'La "guérison" de la leucémie dite aiguë', La Presse Médicale, 1948, 28: 302; Marcel Bessis, 'Sur les exsanguinotransfusions dans les leucémies aiguës', La Presse Médicale, 1948, 29: 360.

${ }^{29}$ Bessis and Dausset, op. cit., note 27 above; Bessis, op. cit., note 28 above.

${ }^{30} \mathrm{~S}$ Farber, L K Diamond, R D Mercer, R F Sylvester and J Wolff, 'Temporary remissions in acute leukemia in children produced by folic acid antagonist, 4-aminopteroyl-glutamic acid (aminopterin)', N. Engl. J. Med., 1948, 238 (23): 787-93.

${ }^{31} \mathrm{~L}$ Meyer, 'Use of folic acid derivates in the treatment of human leukemia', Trans. N Y Acad. Sci., 1948, 11: 75-81; S Farber, 'Some observations on the effect of folic acid antagonists on acute leukemia and other forms of incurable cancer', Blood, 1949, 4 (2): 160-7; Farber, et al., op. cit., note 30 above; J M Stickney, A B Hagedorn, S D Mills and T Cooper, 'Changes in blood and bone marrow in acute leukemia induced by aminopterin', J. Lab. Clin. Med., 1948, 33: 1481; W Jacobson, W C Levin and
}

G Holt, 'Observations on the treatment of acute leukemias with analogues of folic acid', J. Lab. Clin. Med., 1948, 33: 1641-2; M Pierce and H Aalt, 'Treatment of acute leukemia with aminopterin', $J$. Lab. Clin. Med., 1948, 33: 1642-3; W Dameshek, 'The use of folic acid antagonists in the treatment of acute and subacute leukemia', Blood, 1949, 4 (2): 168-71; L M Meyer, H Fink, A Sawitsky, M Rowen and N D Ritz, 'Aminopterin, a folic acid antagonist, in the treatment of leukemia', Am. J. Clin. Pathol., 1949, 19 (2): 119-26; J M Stickney, S D Mills, A B Hagedorn and T Cooper, 'The treatment of acute leukemia with folic acid antagonists', Mayo Clin. Proc., 1949, 24 (21): 525-33; W Dameshek, Chemotherapy of leukemia and leukosarcoma, New York, Grune and Stratton, 1950; Jean Bernard, 'Les nouveaux traitements des leucoses aiguës', Paris Médical, 1951, 41: 285-7; Archives de l'Académie de médecine, Fonds Bessis, correspondence with Jean Bernard, 30 Nov. 1948; correspondence with Jean Dausset, 1948-1949; correspondence with L Diamond, 27 Oct. 1952; correspondence with L Meyer, 5 Oct. 1949. 


\section{Medical Research in Paris Hospitals after the Second World War}

Soon after this introduction of the folic acid antagonists, in 1950, the teams of William Dameshek and Sidney Farber in Boston on the one hand, and of Joseph Burchenal in New York City on the other, announced the induction of remissions in leukaemia following the administration of the hormones ACTH and cortisone. Once again, many trials were launched in several countries. ${ }^{32}$ Within two years, about 250 patients had been treated worldwide. If one considers the number of patients involved, the two main groups participating in the trials were Burchenal's at the Memorial Hospital in New York, and Bernard's at the Saint-Louis Hospital in Paris. As for previous treatments, methods and results were not easily comparable. In particular, the definition of remission still varied greatly from one centre to another. Nevertheless, the different teams reached the same conclusion: the frequency of remissions with ACTH and cortisone was equivalent to that obtained with folic acid antagonists. ${ }^{33}$

Although Bernard and his co-workers initially mimicked Burchenal's practice by using cortisone alone, they soon began combination trials using folic acid antagonists, hormones, and transfusions to treat acute leukaemia in children. From the outset, remission rates were higher than ever before. However, as the mean duration of the disease was not yet accurately determined, it was impossible to assert unambiguously that the treatment prolonged life. The folic acid antagonist and the hormone were either given together, or in succession in order to compare both methods. ${ }^{34}$ Although the two trials were separated by a short interval, comparison was still "historical" in nature. Then, in 1952, Bernard and his colleagues designed their first "comparative" trial. The aim was to assess the value of cortisone for maintenance therapy - as opposed to therapies aiming to induce remission. The children who were in remission at the Saint-Louis Hospital were divided into three groups. Patients from the first group received the same dose of

\footnotetext{
${ }^{32}$ Jean Bernard, 'Les essais de traitement des leucoses aiguës', La Semaine des Hôpitaux de Paris, 1950, 26 (65): 3322-35; idem, 'Les nouveaux traitements des leucoses aiguës', Paris Médical, 1951, 41: 285-7; Jean Bernard and Marcel Bessis, 'Leucémies et glandes endocrines', Le Sang, 1952, 22: 205-33.

${ }^{33}$ O H Pearson, L P Eliel, T R Talbot Jr., J R Burchenal, A T Petro, J W Poppell and L F Craver, 'The use of ACTH and cortisone in acute leukemia', Blood, 1950, 5 (8): 786-7; S Farber, V Downing, B H Kennedy, H Shwachman and R Toch, 'ACTH and cortisone in the treatment of leukemia and allied disorders in childhood', Blood, 1950, 5 (8): 787-9; M M Wintrobe, G E Cartwright, W J Kuhns, J G Palmer and M E Lahey, 'The effects of ACTH on the hematopoetic system', Blood, 1950, 5 (8) : 789-90; J M Stickney, F J Heck and C H Watkins, 'The effect of cortisone and ACTH on diseases of the blood', Blood, 1950, 5 (8): 790; W Dameshek, J Burchenal and E H Reisner in 'Blood Club Third Annual Meeting: ACTH in Leukemia-additional discussion', Blood, 1950, 5 (8): 791-2; S Farber, V Downing, H Shwachman, R Toch, R Appelton, F Herold, J P King and F Feriori, 'The action of
}

ACTH and cortisone in acute leukemia', in John R Mote (ed.), Second Conference on ACTH,

Philadelphia, Blakiston, 1951, vol. 2 (therapeutics), p. 251; M C Rosenthal, R H Saunders, L I Schwartz, L Zannos, E P Santiago and W Dameshek, 'The use of adrenocorticotropic hormone and cortisone in the treatment of leukaemia and leukosarcoma', Blood, 1951, 6 (9): 804-24; Joseph H Burchenal, 'Present status of ACTH, cortisone, and the antimetabolites in the treatment of leukemia and related diseases', in Comptes rendus du $3^{\text {ème }}$ Congrès de la Société internationale européenne d'hématologie (Rome, oct 1951), Rome, E.M.E.S., 1952, pp. 397-407; Bernard and Bessis, op. cit., note 32 above.

${ }^{34} \mathrm{~J}$ Marie, J Bernard, J Salet and C Cruciani, 'Essai de traitement des leucoses aiguës de l'enfant par l'association aminoptérine-cortisone', Bulletins et Mémoires de la Société médicale des Hôpitaux de Paris, 1951, 67 (15-16): 621-32; Bernard, 'Les nouveaux traitements', op. cit., note 32 above; Jean Bernard and Georges Mathé, 'Etude des leucoses aiguës de l'enfance traitées par l'association antifoliques-cortisone', Le Sang, 1952, 23: 12-27; Bernard and Bessis, op. cit., note 32 above. 


\section{Christelle S Rigal}

cortisone during remission as during induction. Patients from the second group took cortisone at a lower dose, and for children from the third group the hormonal treatment was discontinued. ${ }^{35}$

The pharmacopoeia against leukaemia was then enriched by another emblem of cancer chemotherapy: 6-mercaptopurine. Burchenal's team conducted the first clinical studies with this new drug, publishing the results in $1953 .{ }^{36}$ Within a year, about twenty American groups and three foreign teams, including Bernard's, had tested this agent. Once again, locally defined criteria rendered the different trials difficult to compare. The assessment of the therapeutic efficacy of 6-mercaptopurine was further complicated by the fact that some investigators gave it alone, whereas others combined it with available drugs. ${ }^{37}$ Given these parallel enterprises, the harmonization of assessment methods seemed increasingly necessary. The question was debated with growing intensity at the international level during the late 1950s. However, even in the 1960s, practices were only partially standardized. ${ }^{38}$

During the 1940s and 1950s, Bernard's team conducted local, independent, therapeutic trials. These involved small numbers of patients, ranging between ten and fifty. Inclusion and evaluation criteria were not formally predetermined. In the first phase, which had the object of inducing remission, no control group was used. It was the clinician's experience of the disease that served as the reference point. Nevertheless, despite his extensive experience, Bernard did not always consider himself able to distinguish between spontaneous remission and remission due to treatment. ${ }^{39}$ Thus he continued to use "historical" controls, the analysis of hundreds of patients' files, which provided him with an estimation of the frequency and duration of spontaneous remissions. Then, at the beginning of the 1950s, Bernard and his co-workers started organizing comparative trials in an attempt to find therapeutic schedules capable of maintaining remissions. They used no placebo, administering instead competing therapies to each different group of patients. These trials were neither randomized, nor double blind. Even if the Parisian team compared their evaluation criteria regularly with those used by American acute leukaemia specialists, they saw no need to align their practices with those of their American colleagues.

We have already seen that in America, from the mid-1950s onwards, clinical trials on acute leukaemia were conducted by the different specialized centres in a similar way, that is to say mainly on the basis of local practices and knowledge and without

\footnotetext{
${ }^{35}$ Bernard and Bessis, op. cit., note 32 above; Jean Bernard and G Deltour, 'Les nouveaux traitements des leucoses', La Semaine des Hôpitaux de Paris, 1953, 29 (67): 3430-1.

${ }^{36} \mathrm{~J}$ Burchenal, D A Karnofsky, M L Murphy, R R Ellison and C P Rhoads, 'Effects of 6mercaptopurine in man', Proc. Am. Assoc. Cancer Res., 1953, 1: 7-8.

${ }^{37}$ R W Miner (ed.), '6-mercaptopurine', Annals of the New York Academy of Sciences, 1954, 60 (2): 183-508, pp. 359-74, 385-508.

${ }^{38}$ Pierre Denoix, 'Critique des méthodes d'évaluation des résultats obtenus par les produits
}

\author{
chimiothérapeutiques en cancérologie clinique', in \\ Jean Bernard and Georges Mathé (eds), La \\ chimiothérapie des cancers et des leucémies, \\ Colloque international du CNRS $\mathrm{N}^{\circ} 74$, Paris, \\ Editions CNRS, 1958, pp. 13-16; Jean Bernard and \\ Georges Mathé, 'Critique des méthodes d'évaluation \\ des résultats obtenus par la chimiothérapie des \\ hémopathies malignes', in ibid., pp. 17-22 ; B H \\ Morrison (ed.), Conference on experimental clinical \\ cancer chemotherapy, National Cancer Institute \\ Monographs $\mathbf{N}^{\circ}$ 3, Bethesda, MD, NCI, 1960, pp. \\ 149-68. \\ ${ }^{39}$ Bernard, op. cit., note 16 above.
}


referring to controlled clinical trial methodology. That situation changed in 1954 with the creation, within the National Cancer Institute (NCI), of the Cancer Chemotherapy National Committee (CCNC). The new committee was directed by Sidney Farber, and was responsible for co-ordinating the relationship between government, industry, and institutions. One year later, under pressure from the United States Congress and from oncologists outside the NCI, the Cancer Chemotherapy National Service Center (CCNSC) was set up to replace the CCNC. The main mission of this new agency was to supervise pharmacological and other pre-clinical tests, in addition to organizing co-operative clinical trials, thereby bringing together the numerous American teams and, later, foreign teams as well. Within the CCNSC, clinical trials on childhood acute leukaemia were organized by the Acute Leukaemia Group B (ALGB), which soon became the Cancer and Acute Leukaemia Group B (CALGB). ${ }^{40}$ This was not a mere change of sponsor and organization. Scaling-up had important consequences for the practices involved and the knowledge produced, for standardization was perceived as the condition for fruitful co-operation, transferability of results, and speed of evaluation of candidate molecules.

The first co-operative study on leukaemia organized under the aegis of the CCNSC involved four American centres, and included sixty-five patients who were treated between May 1955 and October 1956. This study aimed at comparing two modes of combination of 6-mercaptopurine and amethopterine. In the first case, the folic acid antagonist was given continuously, and in the second, only intermittently. The results, published in 1958, showed that remission and survival lasted longer under the continuous regimen. Considering the methodological aspects of their study, the authors of the report, which cited the work of the British statisticians Austin Bradford Hill and Ronald Fisher, insisted upon the adequacy of their approach compared with the principles of the controlled clinical trial. Patients had been paired according to their age and type of leukaemia, before being randomly allocated to one or other treatment group. For each type of treatment, a detailed protocol had been drawn up and strictly followed. The authors also emphasized the ethical aspects taken into consideration when designing the trial. They argued that this kind of trial was not prejudicial to patients, because the median survival time obtained was similar to that recently published elsewhere in the literature. ${ }^{41}$

The second trial on acute leukaemia organized under the CCNSC involved eleven American centres. Its objectives were to compare treatment with 6-mercaptopurine alone on the one hand, with treatment combining 6-mercaptopurine and azaserine on the other. This randomized controlled trial took place between December 1955 and March 1957, and involved 168 patients. The protocol was elaborated in co-operation with Irwin Bross, from Cornell University Medical College. Compared to the previous trial, its novelty lay

\footnotetext{
${ }^{40}$ Löwy, Between bench and bedside, op. cit., note 1 above, pp. 39, 42-7, 54-61; Peter Keating and Alberto Cambrosio, 'From screening to clinical research: the cure of leukemia and the early development of the cooperative oncology groups, 1955-1966', Bull. Hist. Med., 2002, 76: 299-334.
}

\footnotetext{
${ }^{41}$ E Frei III, J F Holland, M A Schneiderman, D Pinkel, G Selkirk, E J Freireich, R T Silver, G L Gold and W Regelson, 'A comparative study of two regimens of combination chemotherapy in acute leukemia', 1958, Blood, 13 (12): 1126-48.
} 


\section{Christelle S Rigal}

in the fact that patients were receiving their first leukaemia therapy in the context of this trial. No significant difference was observed between the two forms of treatment. ${ }^{42}$ Another trial, published in 1960, used placebo and double-blind assessment. It aimed at determining the therapeutic value of a new compound, 6-azauracil, in cases of leukaemia that were resistant to the usual treatments. The protocol was designed in collaboration with the statistician Edmund Gehan. Paradoxically, the main conclusion reached by this trial was that the use of a placebo was not necessarily required. Since 6-azauracil was inactive against the disease, the trial was judged convenient for use as a control in subsequent trials. $^{43}$

Another methodological innovation, sequential analysis, was introduced in an ALGB study conducted in 1959 and 1960. This co-operative trial, also elaborated with Gehan, investigated the effect of 6-mercaptopurine on the duration of the remission induced by steroids. Patients in remission were selected at random, and were given 6-mercaptopurine or a placebo according to a double-blind procedure. When in relapse, the patients who were given the placebo received 6-mercaptopurine. The sequential analysis of the results allowed the trial to be stopped after remission lengths were observed in twenty-one pairs of patients, since the benefit of a maintenance therapy with 6-mercaptopurine had been proved. On sequential analysis, the paper referred to the work of Peter Armitage, a collaborator of Bradford Hill. Otherwise, the authors of the report also drew attention to the ethical value of controlled trials. They argued that the use of a placebo had no significant effect on survival time, and that this therapeutic schedule therefore allowed new products to be tested while providing the best treatment. $^{44}$

Controlled clinical trials organized by the ALGB had, as already mentioned, very little or no influence on the assessment of new treatments in Paris during the second half of the 1950s. Surprisingly, they also had little impact on the practices of Burchenal's team, despite its participation in one of the first CCNSC trials. ${ }^{45}$ In a trial performed in the mid-1950s, which aimed to compare treatment with 6-mercaptopurine to treatment with 6-chloropurine, only about forty patients participated. Moreover, the results were compared to those of a local historical control group, and the report did not include any references to statistical methodology, although the criteria for evaluating results were those of the CCNSC. ${ }^{46}$

All these observations suggest that at the end of the 1950s, local norms coexisted with standard protocols for the conduct of therapeutic trials both in Europe and in the United

\footnotetext{
${ }^{42}$ R M Heyn, C A Brubaker, J H Burchenal, H G Cramblett and J A Wolff, 'The comparison of 6mercaptopurine with the combination of 6mercaptopurine and azaserine in the treatment of acute leukemia in children: results of a cooperative study', Blood, 1960, 15 (3): 350-9.

${ }^{43}$ E J Freireich, E Frei III, J F Holland, D Pinkel, O Selawry, H Rothberg, F Haurani, R Taylor and E A Gehan, 'Evaluation of a new chemotherapeutic agent in patients with 'advanced refractory' acute leukaemia. Studies of 6-azauracil', Blood, 1960, 16 (3): 1268-78.
}

\footnotetext{
${ }^{44}$ E J Freireich, E A Gehan, E Frei III, L R Schroeder, I J Wolman, R Anbari, A O Burgert, S D Mills, D Pinkel, O Selawry, et al., 'The effect of 6mercaptopurine on the duration of steroid-induced remissions in acute leukemia: a model for evaluation of other potentially useful therapy', Blood, 1963, 21 (16): 699-716.

${ }^{45}$ Heyn, et al., op. cit., note 42 above.

${ }^{46}$ R R Ellison, D A Karnofsky and J H Burchenal, 'Clinical evaluation of 6-chloropurine in leukemia of adults', Blood, 1958, 13 (8): 705-24.
} 


\section{Medical Research in Paris Hospitals after the Second World War}

States. Was this also the case in the 1960s, when the NCI model of chemotherapeutic research and the RCT standard seem to have become generalized?

Links between the Paris unit and the NCI leukaemia task forces were formalized in the early 1960s. After Michel Boiron contacted the ALGB during a research trip to the United States in 1962, Bernard's team was included in the randomized co-operative trial ALGB 6308, designed to compare the effects of 6-mercaptopurine and methotrexate (amethopterine) in acute leukaemia in adults. In the 1960s, Bernard and his collaborators, mainly Boiron, Claude Jacquillat, and Maryse Weil, participated in six other ALGB trials (protocols 6503, 6601, 6603, 6606, 6706, and 6801). ${ }^{47}$

The relationship between Bernard's team and French medical statisticians followed the same chronology. In the early 1960s, Bernard got in touch with statisticians in Paris, and asked them to help with the CALGB trials. In 1962, he took advice from the mathematician Daniel Schwartz while preparing a report on the effect of treatments on survival. Schwartz was the leader of a small group of medical statisticians, formed in the mid-1950s, whose members were more inclined to identify themselves with laboratory workers than with public health officers, and who established themselves within biomedical research by offering their services to "neo-clinicians". ${ }^{8}$ Two of his colleagues, Robert Flamant and Philippe Lazar, were deeply involved in the development of therapeutic trial methodology in France. ${ }^{49}$ However, close collaboration between Bernard and local medical statisticians truly began only in 1966, when Nicole Feingold, a statistician from the Institut National d'Hygiène, which had recently been renamed Institut National de la Santé et de la Recherche Médicale (INSERM, the National Institute for Health and Medical Research), joined Bernard's institute at the Saint-Louis Hospital. ${ }^{50}$

Publications by the Paris team show the coexistence, during the 1960s, of three types of therapeutic trial: first, "preliminary" trials; second, "home-made" protocols designed and conducted exclusively at the Saint-Louis Hospital; third, ALGB protocols. ${ }^{51}$ The "preliminary" trials of Bernard's team used "traditional" methodology, involving a small number of patients and historical controls, and relying on clinical experience. In contrast

\footnotetext{
${ }^{47}$ Archives Nationales, Versement 2002192, article 67, Hématologie expérimentale, letter from Michel Boiron to Jean Bernard, 20 Nov. 1962 ; R R Ellison, B Hoogstraten, J F Holland, R N Levy, S L Lee, R T Silver, L A Leone, T Cooper, R A Oberfield and A Ten Pas, 'Intermittent therapy with 6mercaptopurine (NSC-755) and methotrexate (NSC740) given intravenously to adults with acute leukemia', Cancer Chemother. Rep., 1972, 56 (4): 535-42; R R Ellison, J F Holland, M Weil, C Jacquillat, M Boiron, J Bernard, A Sawitsky, F Rosner, B Gussoff, R T Silver, 'Arabinosyl cytosine: a useful agent in the treatment of acute leukemia in adults', Blood, 1968, 32 (4): 507-23; J Bernard, M Boiron, C Jacquillat and M Weil, 'Recent results in acute leukemias at the Hospital SaintLouis', Recent Results Cancer Res., 1973, 43: 151-4; M Weil, O J Glidewell, C Jacquillat, R Levy, A A
}

Serpick, P H Wiernik, J Cuttner, B Hoogstraten, L Wasserman, R R Ellison, et al., 'Daunorubicin in the therapy of acute granulocytic leukemia', 1973, Cancer Res., 33 (5): 921-8.

${ }^{48}$ See Luc Berlivet's contribution to this issue.

${ }^{49}$ Luc Berlivet, 'Exigence scientifique et isolement institutionnel: l'essor contrarié de l'épidémiologie française dans la seconde moitié du XXe siècle', in Jorland, et al. (eds), op. cit., note 3 above, pp. 335-58.

${ }^{50}$ Archives Nationales, Versement 2002192, article 66, Laboratoire d'immunologie des tumeurs, échanges d'informations entre le directeur de l'institut et Nicole Feingold.

${ }^{51}$ For instance, study ALGB 6706 was elaborated following "preliminary results" from Jean Bernard's team, see Weil, et al., op. cit., note 47 above. 


\section{Christelle S Rigal}

to the 1950s trials, in which new drugs had first been tested on patients in relapse or nonresponsive to usual treatments, these "preliminary" trials tended to include previously untreated patients. $^{52}$

Meanwhile, similar preliminary trials were being conducted by Burchenal's team, although they differed in two respects from the French ones. First, in 1967, the American group started collecting informed consent forms from participants; second, they continued to recruit patients in relapse. ${ }^{53}$ When the new therapeutic agents tested on a small scale were judged promising, they were then included in the "Paris" or ALGB protocols. The Paris protocols were elaborated at the Saint-Louis Hospital by a chemotherapy committee chaired by Bernard. ${ }^{54}$ Unlike the ALGB protocols, they did not use randomization for the evaluation of the induction of remission. ${ }^{55}$ Randomization was not introduced until 1966, in protocol Paris 06 LA 66, as part of maintenance therapy, so that only half of the patients were given immunotherapy to complement chemotherapy. ${ }^{56}$

Although the organization of clinical trials in France seems to have been influenced by American practices, the ALGB was not the only model used. Nor did the transfer of knowledge and practices between centres go in only one direction, since ALGB trials were designed to answer questions posed by "home-made" trials, including the Paris trials. Moreover, criteria for assessing treatments resulted from convergence, rather than alignment, with the ALGB. In 1956, the Clinical Studies Panel of the CCNSC published criteria for the evaluation of responses to treatment in acute leukaemia. These were: A for marrow, B for peripheral blood, C for physical findings, and D for symptoms. Complete remission implied a reversal to normal, both haematologically and clinically, with a rating of 1 in all four categories (A1B1C1D1). Relapse was considered to occur when the patient's condition deteriorated in any category (A3B3C3D3). Other

\footnotetext{
${ }^{52}$ M Boiron, C Jacquillat, M Weil and J Bernard, 'Combination of methylglyoxal bis(guanylhydrazone) (NSC-32946) and 6-mercaptopurine (NSC-755) in acute granulocytic leukemia', Cancer Chemother. Rep., 1965, 45: 69-73; M Boiron, M Weil, C Jacquillat, J Tanzer, D Levy, C Sultan and J Bernard, 'Daunorubicin in the treatment of acute myelocytic leukemia', Lancet, 1969, 1: 330-3; C Jacquillat, M Weil, A Bussel, J P Loisel, T Rouesse, M J Larrieu, M Boiron, B Dreyfus and J Bernard, 'Treatment of acute leukemia with Lasparaginase-preliminary results on 84 cases', Recent Results Cancer Res., 1970, 33: 263-78; C Jacquillat, M Weil, M-F Gemon, G Auclerc, J-P Loisel, J Delobel, G Flandrin, G Schaison, V Izrael, A Bussel, et al., 'Combination therapy in 130 patients with acute lymphoblastic leukemia (protocol 06 LA 66-Paris)', Cancer Res., 1973, 33 (12): 3278-84; C Jacquillat, M Weil, M F Gemon-Auclerc, V Izrael, A Bussel, M Boiron and J Bernard, 'Clinical study of rubidazone (22 050 R.P.), a new daunorubicinderived compound, in 170 patients with acute leukemias and other malignancies', Cancer, 1976, 37 (2): 653-9.
}

\footnotetext{
${ }^{53}$ B Clarkson, I Krakoff, J Burchenal,
} D Karnofsky, R Golbey, M Dowling, H Oettgen and A Lipton, 'Clinical results of treatment with E. coli L-asparaginase in adults with leukemia, lymphoma, and solid tumors', Cancer, 1970, 25 (2): 279-305.

${ }^{54}$ Archives Nationales, Versement 2002192 , article 80, Chimiothérapie, letters from Jean Bernard to Claude Jacquillat, Dec. 1964, 23 Feb. 1965.

${ }^{55}$ For protocols 02LA64 et 04LA65, see C Jacquillat, M Weil and M Boiron, 'Effets de la méthode de réinduction au cours du traitement des leucémies aiguës lymphoblastiques', Nouv. Rev. Fr. Hémat., 1967, 7 (5): 677-82. For protocol 06 LA 66, see Jean Bernard, 'Chimiothérapie des leucémies et des hématosarcomes', in Comptes rendus du $37^{i e m e}$ congrès français de médecine, Paris, Masson, 1969, pp. 45-67. For protocol 01LA69, see Archives Nationales, Versement 2002192, article 11, correspondence with Robert Flamant, 26 Feb.1973, 13 March 1973.

56 Jacquillat, et al., 'Combination therapy', op. cit., note 52 above. 
situations were called partial remissions. To qualify for an A1 rating, marrow was not to exceed 5 per cent blast cells in adults, and 10 per cent in children. ${ }^{57}$ This threshold of 10 per cent was criticized by Bernard, who in 1962, having compiled 300 files of children treated in his department between 1955 and 1960, proposed his own haematological criteria for complete remission. For Bernard, bone marrow had to contain less than 5 per cent blast cells, even in children. ${ }^{58}$ The Paris team therefore amended the CCNSC criteria accordingly. ${ }^{59}$ The same 5 per cent threshold was also adopted by the Midwest Cooperative Chemotherapy Study Group-bringing together centres from Ohio, Iowa, Michigan, Missouri, Illinois, Wisconsin and Indiana-for the purpose of analysing the results of a trial published in 1964. In order to define responses to treatment with greater accuracy, the co-operative group also modified the categories for evaluation. Categories $\mathrm{ABCD}$ were replaced by MHPS (corresponding to $\mathrm{M}$ for marrow, $\mathrm{H}$ for haematological criteria, $\mathrm{P}$ for physical findings, and $\mathrm{S}$ for symptoms). Within each category, parameters were graded between 1 and 5. Four disease states could thus be defined: $\mathrm{A}=$ no evident disease, $\mathrm{B}=$ moderate disease, $\mathrm{C}=$ extensive disease, $\mathrm{D}=$ extreme disease. A corresponded to a rating of 1 in all categories $(\mathrm{M}, \mathrm{H}, \mathrm{P}$ and $\mathrm{S}$ ). Five terms were then used to describe the response to therapy. Thus, "Improvement of disease status A" referred to complete remission. ${ }^{60}$

Finally, during the 1960s, the transformation of the therapeutic trials conducted by Bernard's team was partially inspired by the controlled clinical trial methodology promoted by ALGB statisticians. However, the organization of clinical trials continued to be governed mainly by local norms. This feature was not specific to France, for it also characterized the leading American centres devoted to leukaemia research. Thus, the Paris protocols competed with "home-made" protocols from the Memorial Hospital, the NCI, ${ }^{61}$ or the Detroit Children's Hospital. ${ }^{62}$ In the mid-1960s, discrepancies between practices were probably seen as less problematic than during the previous decade, because analysis of the outcomes of early chemotherapeutic trials had revealed that a few children were living in remission for more than five years, even though they had been treated in various ways in different centres, for different types of acute leukaemia. ${ }^{63}$

Just as in the 1950s, local and international norms coexisted in Europe and the United States in the therapeutic trials in onco-haematology carried out in the 1960s.

\footnotetext{
${ }^{57}$ Harry F Bisel, 'Criteria for the evaluation of response to treatment in acute leukemia', Blood, 1956, 11: 676-7.

${ }^{58}$ J Bernard, M Boiron, M Weil, J-P Lévy, M Seligmann and Y Najean, 'Etude de la rémission complète de la leucémie aiguë (analyse de 300 cas)', Nouv. Rev. Fr. Hématol., 1962, 2: 195-222.

${ }^{59}$ Ellison, et al., 'Intermittent therapy', op. cit., note 47 above.

${ }^{60} \mathrm{~J}$ S Hewlett, J D Battle Jr, R C Bishop, W M Fowler, S O Schwartz, P S Hagen, J Louis, 'Phase II study of A-8103 (NSC -25154) in acute leukemia in adults', Cancer Chemother. Rep., 1964, 42: 25-8.

${ }^{61}$ E Freireich, M Karon, E Frei III, 'Quadruple combination therapy (VAMP) for acute lymphocytic
}

leukemia of childhood', Proc. Am. Ass. Cancer Res., 1964, 5: 20-76.

${ }^{62}$ Wolf W Zuelzer, 'Implication of long-term survival in acute stem cell leukemia of childhood treated with composite cyclic therapy', 1964, Blood, 24 (5): 477-94.

${ }^{63}$ Jean Bernard, 'Les leucémies de l'enfant', Päd. Fortbildungskurse, 1964, 11-12: 1-15; Joseph $\mathrm{H}$ Burchenal and M Lois Murphy, 'Long-term survivors in acute leukemia', 1965, Cancer Res., 25 (9): 1491-4; Zuelzer, op. cit., note 62 above; Jean Bernard and Marcel Bessis, 'Peut-on guérir les leucémies?', Nouv. Rev. Fr. Hémat., 1965, 5 (2): 209-12. 


\section{Christelle S Rigal}

Nevertheless, given the changing organization of cancer clinical research in the United States, the internationalization of the trials, and the circulation of statistical tools, these local and international norms gradually converged. In 1959, a conference on "controlled clinical trials", organized by the Council for International Organizations of Medical Sciences, was held in Vienna under the chairmanship of Austin Bradford Hill. A comparison between the introductory papers co-ordinated by Hill, and the French report written by Schwartz and his colleagues, shows very few differences. All mentioned the same goals, ethical considerations, and methods. Thus, they agreed that retrospective controls-although widely applied in the past-should be avoided, that treatments should be allotted using tables of random sampling numbers, and that giving one drug in one centre and a competing treatment in another, or giving different treatments concurrently without preliminary randomization, made valid comparisons impossible. Other common rules were the use of double-blind assessment, and the fact that the decision to enter a patient in a trial had to be made before randomization. Both the British and the French groups tolerated certain departures from the ideal of the controlled trial. These included the use of the patient as his or her own control, concurrent assessment, and sequential analysis. Moreover, clinical trials in malignant disease were considered to be peculiar but valuable despite obvious difficulties. According to both French and British statisticians, cancer trials required the use of percentage survival for a period of at least five years as an index of curative value. Moreover, they accepted that initial treatment could be determined by random methods and that then, at a later stage, the patient could be given the best treatment. Lastly, double-blind trials were generally found to be impractical for cancer. ${ }^{64}$

\section{The Clinical Vision of Medical Progress and Government Rationalization}

The "experimentalization" of the clinic in France, in onco-haematology, was rooted in political and institutional change. The general idea that medical progress depended on the pursuit of systematic, large-scale, co-operative investigations circulated amongst young physicians and health officials in the 1950s, and was largely accepted by the 1960s. However, the notion that medical progress was associated more specifically with controlled trials, conducted on human subjects and investigating the activity of chemotherapeutic agents, was invented and promoted by the physicians. As mentioned above, the reform of medical teaching and hospital organization that was adopted in 1959 and implemented in the 1960s played a crucial role in the acceptance of this particular interpretation of biomedicine. The reform itself resulted from the alliance between medical reformers and state administrators who believed that planning and large-scale socio-technical programmes were the best way to rationalize and modernize French society. Thus the ideas of "neo-clinicians" benefited from an unexpected influence within government. ${ }^{65}$

\footnotetext{
${ }^{64}$ Controlled clinical trials, Oxford, Blackwell Scientific Publications, 1960; D Schwartz, R Flamant, $\mathrm{J}$ Lellouch and C Rouquette, Les essais thérapeutiques cliniques. Méthode scientifique d'appréciation d'un traitement. Rapport interprétatif
}

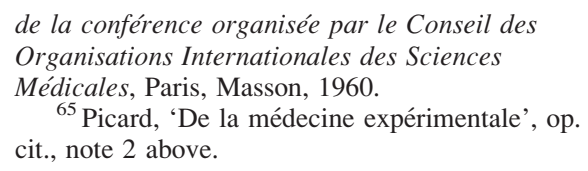




\section{Medical Research in Paris Hospitals after the Second World War}

On the occasion of Bernard's seventieth birthday, Jean Hamburger wrote of Bernard's role and of what had inspired their self-defined and self-organized group of neoclinicians:

Jean Bernard has always been for me - and for many others I guess-a model. I thank the Nouvelle Revue Française d'Hématologie for offering me this unique opportunity to explain why I admire him so much. The first reason is that Jean Bernard is a physician who is convinced that medicine can no longer do without the method, humility, and reasoning of science. He has said that: "contemporary medicine ... is animated by the spirit and rigour of biology ... Nothing is more outdated than the scholastic dispute about the nature of medicine that divided those who took it for an art, and those for whom it was a science. Medicine is assuredly a science." Our generation entered French medicine while it was still hesitating on that point, resisting the massive input of chemistry, physics, and mathematics into medical research. That was when, together with some friends, we created the Club des Treize. The Club met almost clandestinely to talk about the medicine we dreamt of, a medicine in which issues would be investigated with the same rigour as in other scientific disciplines. ${ }^{66}$

The members of this Club des Treize met once a month in Robert Debré's department at the Hôpital Necker. Initially, they numbered thirteen, but soon some forty physicians had been invited to join the group, which was then renamed the Cercle d'Etudes Cliniques et Biologiques (Clinical and Biological Studies Circle) ${ }^{67}$ Bernard often discussed the need to enrich medical research with the knowledge and practices of other disciplines. For instance, in 1966, he observed that: "every science is measurement... . By becoming measurement, medicine ceases to be magic." Consequently, he thought the distinction between "clinical" and "para-clinical" examination to be unfounded, since "what matters is not the organ that perceives the abnormalities, but the mind that interprets them". ${ }^{68}$ Bernard also used to say that clinical observation had often stimulated biological studies, and that medical research was characterized by a "fertile double-stream" linking data collection and experimentation. ${ }^{69}$

\footnotetext{
66 "Jean Bernard a toujours été pour moi-et sans doute pour bien d'autres_-un modèle. Je remercie la Nouvelle Revue Française d'Hématologie de me donner cette occasion unique d'expliquer quelquesunes des raisons pour lesquelles je l'admire tant. La première raison est que Jean Bernard est un médecin convaincu que la médecine ne peut plus se passer de la méthode, de l'humilité, du mode de raisonnement scientifiques. Il a proclamé "La médecine contemporaine ... est animée par l'esprit, par la rigueur de la biologie... . Rien de plus périmé que la dispute scholastique sur la nature de la médecine opposant ceux qui la tiennent pour un art à ceux qui la tiennent pour une science. La médecine est assurément une science.' La génération à laquelle nous appartenons, lui et moi, avait trouvé une médecine française hésitant encore sur ce point, boudant l'entrée en force de la chimie, de la physique, de la mathématique dans la recherche médicale. C'était le temps où, avec quelques amis, nous fondions le Club des Treize. Le Club se réunissait presque clandestinement, pour parler de la médecine
}

dont nous rêvions, une médecine dont les problèmes seraient abordés avec la même rigueur que celle des autres disciplines scientifiques." Jean Hamburger, 'Hommages à Jean Bernard. Courte note qui n'a rien d'hématologique sur Jean Bernard', Nouv. Rev. Fr. Hématol., 1977, 18 (2): 425-8.

${ }^{67}$ Interview with Jean-François Bach by Suzy Mouchet and Jean-François Picard, 2 Jan. 2001; Picard, 'De la médecine expérimentale', op. cit., note 2 above.

68 "Toute science est mesure. . . . Devenant mesure, la médecine cesse d'être magie... . ce qui compte ce n'est pas l'organe qui recueille les anomalies, c'est l'esprit qui les interprète." Jean Bernard, 'Progrès de la médecine et responsabilité du médecin', in Deuxième congrès international de morale médicale (Paris, 24-27 May 1966), rapports (vol. 1), Paris, Ordre national des médecins, 1966, pp. 261-74.

${ }^{69}$ Archives Nationales, versement 20020192, article 1, Annales de l'Université de Paris, n²4, 1968, p. 648 . 


\section{Christelle S Rigal}

The members of the Club des Treize founded la Revue française d'études cliniques et biologiques (French Review of Clinical and Biological Studies) in 1956. In the first editorial of the journal, Bernard, Hamburger, Paul Castaigne, Charles Debray, René Fauvert, André Lambling, Jean Mathey, Pierre Soulié, and Jean-Pierre Soulier all members of the Club, expressed their views on medical research:

... medical research is different from pure clinical medicine as well as from the so-called basic sciences. It differs from the former, not so much by the methods employed (the examination of a blood test, of an electrical recording, or of an electrophoretic curve, is as much "clinical" as the four classical operations of inspection, palpation, percussion, auscultation), as by a constant attempt at induction. From the latter-the physical, biochemical, and bacteriological sciences-it differs by a permanent human concern, medical research being immediately and directly governed by questions arising from disease. ${ }^{70}$

Building on this concept of scientific medicine, Paris neo-clinicians gradually developed a notion of "clinical medicine" in a broad sense. Whereas in his 1956 scientific autobiography Bernard limited the section on "clinical studies in leukaemia" to descriptions of new categories of the disease, such as "leukaemia in very young children", 71 in a note on his institute's "clinical section" written in 1970, under the heading 'Clinical studies on leukaemia' he included chemotherapy, patient supervision, statistical surveys, and geographical haematology. ${ }^{72}$ Until the Second World War, "clinic" and "clinical", which had entered the French vocabulary 300 years before, still referred to bedside examination. ${ }^{73}$ However, by the end of the twentieth century, both the narrow and the broader sense of "clinical medicine" coexisted. The first referred to what a clinician does when he or she is confronted with a patient in the consulting room or at the bedside. The second referred to any resource-whether biology, chemistry, physics, mathematics, psychology, or sociology — which could be used for diagnosis, prognosis, treatment and prevention. ${ }^{74}$ By the end of the 1960s, most physicians involved in the

\footnotetext{
70 “... la médecine de recherche diffère aussi bien de la clinique pure que des sciences dites fondamentales. De la première, elle se distingue non pas tant par les méthodes utilisées (l'examen d'une lame de sang, d'un tracé électrique ou d'une courbe d'électrophorèse est tout aussi 'clinique' que les quatre opérations classiques d'inspection, palpation, percussion, auscultation) que par une constante volonté d'induction. Des secondes-sciences physiques, biochimiques, bactériologiques,-elle se sépare par une constante préoccupation humaine, les questions posées par la maladie gouvernant immédiatement et directement les recherches." Editorial, Revue française d'études cliniques et biologiques, 1956, 1 (1): 15.

${ }^{71}$ Bernard, op. cit., note 7 above.

${ }^{72}$ Archives Nationales, Versement 20020192, article 1 , Note sur les recherches poursuivies à l'UER d'hématologie, 1970.

${ }^{73}$ In French, the noun clinique was introduced in 1586. The term is derived from the Latin clinice and
}

from the Greek klinikê which means medicine performed at the bedside. The adjective clinique entered French vocabulary seventy years later in the term "médecine clinique" (clinical medicine). Since 1808 the noun clinique has also meant medical teaching at the bedside and since 1814 has signified the place where this teaching is imparted. The noun clinique has also been used, since 1890 , to denote a place for medical care. See P Imbs (ed.), Trésor de la langue française. Dictionnaire de la langue du XIXe et du XXe siècle (1789-1960), Paris, Editions du CNRS-Gallimard, 1977, vol. 5, pp. 923-4;

Alain Rey (ed.), Dictionnaire historique de la langue française, Paris, Dictionnaires Le Robert, 1992, p. 434.

${ }^{74}$ Christopher Lawrence, 'Clinical Research', in Krige and Pestre (eds), op. cit., note 1 above, pp. 439-59; Christiane Sinding, 'Biologie et médecine (histoire)', in Lecourt (ed.), op. cit., note 17 above, pp. 164-9. 


\section{Medical Research in Paris Hospitals after the Second World War}

management of medical research had adopted this broad definition of clinical research. This is reflected in the report of a colloquium on scientific policy and biomedical research, held in Paris in 1968, organized by UNESCO, and chaired by Bernard. During this event, the Swedish Minister of Health, Bror Rexed, explained his view of clinical research:

I call clinical research all research centred on patients, both in laboratories, and in hospitals. Of course, we could simply call it biomedical research, but that would be futile since it would be difficult for a biologist to be profoundly involved in such research. The researcher must be a physician, because he must take care of patients, take responsibility for them, and treat them one way or another. Sometimes biologists, physicists, and engineers belong to teams dedicated to resolving clinical issues. But eventually, medical responsibility falls upon the physician. ${ }^{75}$

This vision of medical progress resonated with the political climate of the 1950s, when state initiatives were viewed as central to the modernization of French society, above all to the growth of its economic capacity. Rationalization, control, and government planning were also important in health matters, since after the introduction of Sécurité Sociale in 1945 a major responsibility of the state was to guarantee access to care, a role for which a state-based medical research policy was deemed indispensable. Such a vision represented a radical departure from the pre-war situation. Before the Second World War, French medical research had attracted little financial support. Research laboratories were rare in medical universities and hospitals. In 1946, few hospital laboratories existed. They were badly equipped and mainly performed a "service role", i.e. routine biochemical, bacteriological, or cytological analysis. Small funds for animals or reagents came either from universities, or from the newly created Centre National de la Recherche Scientifique (CNRS, the National Centre for Scientific Research), and occasionally from private associations or individuals. Instruments and materials, which were also used for diagnosis and treatment, belonged to the hospitals. In 1941, the Vichy government created the Institut National d'Hygiene. The resources of this institute were, however, very limited. The INH supported only research on matters for which the regime sought specific expertise, concerning nutrition, the physiology of reproduction, and more importantly epidemiological investigations. After the war the budget of the INH was still far inferior to that of the CNRS. ${ }^{76}$

In 1947, several physicians from the Assistance Publique in Paris, Bernard among them, founded the Association pour le Développement de la Recherche Médicale Française (Association for French Medical Research) for the purpose of collecting charitable donations. A few years later, in 1953, the Association Claude Bernard pour le Développement

\footnotetext{
75 “... je nomme recherche clinique, toutes ces recherches centrées sur les malades, que ce soit dans les laboratoires ou dans les hôpitaux. On pourrait bien sûr la nommer aussi simplement recherche biomédicale. Cependant, cela ne serait guère utile, car un biologiste aurait des difficultés à s'engager très loin dans cette recherche. Il faut que le chercheur ici soit médecin, car il doit s'occuper de malades, les prendre sous sa responsabilité et les traiter d'une manière ou d'une autre. Il arrive que des biologistes, des physiciens et des ingénieurs fassent partie de
}

d'équipes attachées aux problèmes de la science clinique, mais il n'en reste pas moins que la responsabilité médicale incombe à un médecin." Comptes rendus du Colloque sur la politique scientifique et la recherche biomédicale, Paris, 26-29 février 1968, Paris, UNESCO, 1970, pp. 11-12.

${ }^{76}$ Archives de 1'Institut Pasteur, dossier CNRS 1945-1946, Commission interministérielle de la recherche, Rapport de la sous-commission recherche médicale et thérapeutique; Picard, op. cit., note 2 above. 


\section{Christelle S Rigal}

des Recherches Biologiques et Médicales dans les Hôpitaux de l'Assistance Publique à Paris (Claude Bernard Association for Biological and Medical Research in Paris Hospitals) was created by a consortium of institutions, including the Paris city council, the Department of the Seine, the CNRS, the INH, the Sécurité Sociale (the French health service), the Assistance Publique and the Association pour le Développement de la Recherche Médicale Française. A proposal for this association had already been submitted to the city council in 1942, but had been rejected. The creation of the Association Claude Bernard was made possible by the appointment of a health officer, Xavier Leclainche, at the head of the Assistance Publique, and of a research-oriented physicist and physician, who had met Debré and Louis Pasteur-Vallery-Radot during the Resistance, Louis Bugnard, at the head of the $\mathrm{INH}^{77}$

State support for medical research intensified at the end of the 1950s. During the Second Plan (1952-57), the French industrial planning commission (Commissariat général au plan)_an institution established in 1946 to facilitate economic reconstructioncreated a special commission for scientific and technical research, which considered issues of medically related biological investigations. In 1954, Georges Champetier, deputy director of the CNRS, and Mr Schwob, chief inspector at the Ministry of Industry, wrote its first general report. They suggested developing existing medical research centres, supplying them with equipment, appointing more medical researchers, training them in the basic sciences, and encouraging the relationship between medical research and industry. They also proposed the creation of a structure similar to the British Medical Research Council. Finally, they considered the standardization of laboratory animals and therapeutic molecules, such as antibiotics and hormones, to be an urgent task. The creation of a national centre for scientific equipment and of a general bibliographic service were also part of their modernization plan. ${ }^{78}$

However, such structures were not established until the end of the decade, after Charles de Gaulle had seized power and his government turned science policy into a national priority and scaled-up its investment in research. One exemplary initiative was the creation of an interdepartmental administration for the promotion of scientific and technical research created in 1958. This Délégation générale targeted a few domains requiring emergency support. Nine committees (comités d'actions concertées) were created with a handful of scientists in charge of each programme. Cancer and leukaemia were among the chosen fields. ${ }^{79}$ The need for extraordinary funding was justified by contrasting public expenditure on medical research in France with that of the United States and Great Britain: in 1959, the budget of the INH was 7 million francs, the budget of the British Medical Research Council the equivalent of 49 million francs, while

\footnotetext{
${ }^{77}$ Archives Nationales, Versement 2002192, article 162, Association Claude Bernard: statuts, 1956; ibid., brochure de présentation des travaux pour 1955-1970; Jean Bernard, 'Leçon inaugurale de la chaire de cancérologie médicale et sociale', La Presse Médicale, 1956, 64 (65): 1487-91; Louis Bugnard, 'Editorial', Radioprotection, 2006, 41 (3): $273-4$.
}

\footnotetext{
${ }^{78}$ Archives Nationales, Mission du Ministère de la recherche, cote H.C.S.54.448, Commissariat général au plan de modernisation et d'équipement, Commission de la recherche scientifique et technique, 'Rapport général', 1954.

${ }^{79} \mathrm{G}$ Bidault, Les mémoires de la recherche-Etats des versements 1977-1989, Paris, CNRS Editions, 1993.
} 


\section{Medical Research in Paris Hospitals after the Second World War}

the US Congress awarded 750 million francs to the National Institutes of Health in that same year. ${ }^{80}$

The Cancer and Leukaemia Committee began work in 1960 with eleven members, including Jean Bernard and Marcel Bessis. The allocation of funds started in July 1961. The committee selected three forms of intervention: support for research on cancer cell and tumour growth; provision of specific training in cancer research; and the creation of laboratories and purchase of equipment. According to the committee, the study of cancer at the cellular and molecular levels was essential, high hopes being placed on the development of biochemistry and electron microscopy. However, the committee refused to support therapeutic trials. Moreover, the search for chemotherapeutic compounds was explicitly rejected on the grounds that it necessitated vast structures of the kind only American institutes could afford. The Cancer and Leukaemia Committee funded French teams on the basis of their reputation, and over a wide range of cancer research to minimize competition between teams. In 1961, the decision was made to fund thirteen research centres, to train 100 researchers, and to create two new institutes and six research units. ${ }^{81}$

Immediately after the war, the creation of laboratories within hospitals had been hindered by the situation of physicians, who spent only part of their time in the hospital, and the rest either in the university or in private practice, with the result that few advocated the creation of teaching hospitals. However, in 1959, President de Gaulle chose Michel Debré, son of Robert Debré, as his prime minister. Under these circumstances, the reform of medical education, which the latter had been advocating for decades, was at last realized. This reform eliminated the dual nature of French medical careers, previously shared between university and hospital. Under the new arrangements, hospitals and medical schools were to be jointly responsible for medical care, teaching, and research, and were to reorganize all their services in order to implement this triple mission. The hospital and academic careers of physicians were merged. Each hierarchical level became characterized by two titles and two functions. Geographic concentration lay at the heart of the project, with a view to promoting interdisciplinary collaboration and increased efficiency. The medical reform plan was implemented in $1963 .{ }^{82}$

Within a few years, encouraged by these institutional changes, Bernard no longer considered it a good policy to let American teams do most of the research in cancer chemotherapy. In preparation for the Sixth Plan, which was to begin in 1970, he requested the creation of another committee to support four or five teams conducting original research on the subject. By then, chemotherapy was not only seen to be the core of therapeutic research, it was also perceived as a set of questions, resources, and

\footnotetext{
${ }^{80}$ Archives Nationales, Mission du Ministère de la recherche, cote H.C.S.54.448, Commissariat général du plan d'équipement et de la productivité, Commission de la recherche scientifique et technique, 'Rapport du délégué général délibéré avec le CCRST', 1961, p. 163.

${ }^{81}$ Archives Nationales, Mission du Ministère de la recherche, Rapport d'activité des actions
}

concertées de la DGRST, 1961; Fonds Bessis, correspondence with Jean Bernard, 6 Jan. 1960.

${ }^{82}$ Archives Nationales, Versement 2002192, article 146, Ministère des affaires étrangères, Rapport de J Bernard et J Dausset sur la réforme des études médicales et de la vie hospitalière en France, 1963; Picard, 'De la médecine expérimentale', op. cit., note 2 above. 


\section{Christelle S Rigal}

tools which "basic" molecular biologists could use to explore cellular growth and cell differentiation. ${ }^{83}$

\section{French Post-war Medical Research: Foreign Models and Local Practices}

The introduction of biological and statistical practices profoundly altered the kind of medical research performed by clinicians from the Assistance Publique des Hôpitaux de Paris after the Second World War. The French medical reformers who called themselves "neo-clinicians" advocated a form of medical research that was not strictly biomedical in the sense of the transfer of biological knowledge and practices into medicine, but rather consisted in the conjunction of two different scientific traditions, the first biological, the second clinical. As many observers have noted, the postwar biologization of medical research was based on the development of the life sciences in particular, which promoted "fundamental" studies of cells and molecules. ${ }^{84}$ During the late 1950s and the 1960s, this trend coincided with the establishment of autonomous biological research laboratories within hospitals, and with what might be thought of as the "mathematization" of clinical research, involving the mobilization of big numbers and statistical tools. However, the gradual transformation of the clinical trials carried out by Bernard and his team reveals that this development was in fact a re-birth of the clinic, a long-term process now perceived as the advent of evidence-based medicine, which, by encouraging the production of standards and norms, led to a greater homogeneity and greater control of medical practice. The development of protocols, the use of control groups, the concern for quantification, and statistical analysis were all means to this end. During the post-war period, the therapeutic trials conducted by Bernard's team thus involved a growing number of patients, protocols became formalized, statisticians contributed to their design and to the evaluation of results, and the Parisian group finally participated in international multi-centre clinical trials. This evolution was closely linked to organizational changes within hospitals, which were becoming places of high-tech and specialized medical intervention required to maintain the health of (almost) the entire nation now included in a general social security system.

Although a culture of controlled human experimentation, based on the mobilization of statistics, and promoting the ideal of the RCT, gradually took root within Paris

\footnotetext{
${ }^{83}$ Archives Nationales, Versement 2002192, article 141, Premier ministre, DGRST, letter to M Maréchal, 22 July 1967; Archives de l'académie de médecine, Fonds Bessis, correspondence with Georges Mathé, 13 March 1967.

${ }^{84}$ Löwy, et al. (eds), op. cit., note 1 above, pp. 181-262; Lily E Kay, The molecular vision of life: Caltech, the Rockefeller Foundation, and the rise of the new biology, New York, Oxford University Press, 1993; I Löwy, 'Experimental systems and clinical practices: tumor immunology and cancer immunotherapy, 1895-1980', J. Hist. Biol., 1994, 27 (3): 403-35; Hans-Jörg Rheinberger, 'Beyond
}

\footnotetext{
nature and culture: a note on medicine in the age of molecular biology', Science in context, 1995, 8: 249-63; Krige and Pestre (eds), op. cit., note 1 above, pp. 439-546; de Chadarevian and Kamminga (eds), op. cit., note 1 above, pp. 139-272; Cooter and Pickstone (eds), op. cit., note 1 above, pp. 347-449; Gaudillière, note 1 above; Keating and Cambrosio, op. cit., note 1 above; Christelle S Rigal, 'Contribution à l'histoire de la recherche médicale: autour des travaux de Jean Bernard et de ses collaborateurs sur la leucémie aiguë, 1940-1970', PhD thesis, Université Paris 7, 2003.
} 


\section{Medical Research in Paris Hospitals after the Second World War}

hospitals, the example of Bernard shows that this change was less radical than is often claimed. Although controlled trial protocols, standards of practice, and statistical tools dominated the methodological discourses of medical reformers, they did not simply replace more traditional forms of aggregating and comparing cases. Several types of trials coexisted and were combined, with and without control groups, with or without mandatory and standardized protocol, some with large, some with smaller numbers of patients. Rather than representing a radical departure from biographical medicine, or an acculturation to evidenced-based medicine, the path to modernization followed at the Saint-Louis Hospital was, in fact, a process of superimposition. Although by the late 1960s a new hierarchy of evidence had emerged, which favoured the RCT as a collective norm if not as a routine, unlike similar developments in the United States and in Britain, and in contrast to the prevailing historiography, its advent in France owed little to statisticians.

Given the leading role that American specialists played in the post-war development of cancer chemotherapy, it might be thought that change in Paris took place largely in order to copy and adapt the American model. The existence of such a model, as well as the circulation of molecules, protocols, results, and researchers between the USA and France did play an important role in Bernard's research trajectory. One outcome of such circulation was the gradual integration of the work done at the Saint-Louis Hospital with a transatlantic community of cancer "trialists" co-ordinated by the NCI. However, it would be misleading to suppose either that American cancer research was an unchallenged model, or that exchanges were one sided. The alignment of Parisian research with research on the other side of the Atlantic was patchy, and the result of convergence rather than imitation. A paradoxical aspect of the complex relationship that connected cancer specialists in France and the USA was that the obligatory theoretical point of reference remained the work of the Medical Research Council's group of statisticians, even if the therapeutic trials were conducted in collaboration with American, not with British, institutions.

One final observation concerns the political support won by this "new" form of medical research in the 1960s. While discussing this success, contemporary observers as well as active participants variously stressed the pressing need for medical modernization, the neo-clinicians' power as a pressure group, and the decisive impulse which political change in 1958 lent to the idea of institutional reform. One previously unnoticed factor revealed by this study is the ideal of co-ordination, control, and standardization which characterized the new cancer chemotherapy. In the United States this culture had strong roots in the pharmaceutical industry, which not only provided the CCNSC with molecules, but also with organizational models. ${ }^{85}$ In the French context, this was not an industrial culture, but an administrative one. During the so-called Trente Glorieuses (the thirty years of economic growth between 1945 and 1975), social management was seen as a state affair, planning was considered indispensable, and its administrative

\footnotetext{
${ }^{85}$ Robert F Bud, 'Strategy in American cancer research after World War II: a case study', Soc. Stud. Sci., 1978, 8 (4): 425-59.
} 


\section{Christelle S Rigal}

implementation was accompanied by a swathe of dispositifs, which were put in place for measuring, quantifying, standardizing, co-ordinating, and enforcing co-operation between social and economic actors. These were mirrored in the controlled clinical trials and other organizational tools developed by the neo-clinicians of the Assistance Publique des Hôpitaux de Paris after the Second World War, among whom Jean Bernard was a key and influential player. 